\title{
ДЖЕРЕЛЬНА БАЗА ДОСЛІДЖЕННЯ ПРОБЛЕМИ ВЗАСМОДІЇ «ВИЩИЙ ПЕДАГОГІЧНИЙ НАВЧАЛЬНИЙ ЗАКЛАД - ЗАГАЛЬНООСВІТНЯ ШКОЛА» В ОСВІТНЬОМУ ПРОСТОРІ УКРАЇНИ
}

\author{
Елла Бурова \\ кандидат педагогічних наук, \\ методист вищої категорії навчально-методичного відділу, \\ ДВНЗ «Донбаський державний педагогічний університет», \\ м. Слов'янськ, Україна \\ ella.burova@ukr.net \\ Костянтин Яровий \\ кандидат педагогічних наук, \\ доцент кафедри обліку і аудиту, \\ ДВНЗ «Донбаський державний педагогічний університет» \\ м. Слов'янськ, Україна \\ yarovoy_k_a@ukr.net
}

Анотація. Проаналізовано та систематизовано джерельну базу дослідження 3 узагальненими теоретичними та практичними висновками, згідно з якою розкрито важливість малодоступних наукових статей вітчизняних учених і науковців, які друкувалися на сторінках педагогічних журналів і науково-методичних періодичних видань, дисертаціях, монографіях. У наукових працях на підставі аналізу філософської, психолого-педагогічної літератури обгрунтовано сутність понять: «взаємодія», «педагогічна взаємодія», у яких підкреслювалась важливість та єдність у стосунках учасників навчального процесу.

Показано досвід попередніх поколінь із розробки теоретичних і практичних здобутків, що $є$ джерелом розвитку й поліпшення взаємодії вищого педагогічного навчального закладу та загальноосвітньої школи. Підкреслено ефективність співпраці в процесі пошуку методів і прийомів з удосконалення педагогічної взаємодії «вищий педагогічний навчальний заклад загальноосвітня школа» з метою наступності.

Ключові слова: джерельна база; взаємодія; педагогічний процес; взаємозв’язок теорії і практики; вищий педагогічний навчальний заклад; загальноосвітня школа.

Постановка проблеми. Одним із основних гіпотетичних питань у сучасній науці $\epsilon$ взаємозв'язок між педагогічною наукою та педагогічною практикою. Чим більше обговорюється ця проблема, тим більше виникає питань стосовно строку реформи освіти та досягнення позитивних результатів. Міністерством освіти і науки України презентовано проєкт Концепції розвитку освіти 2015 - 2025 років, у якому пропонується перехід на 12-річну систему освіти в школах. Насамперед профільне навчання в старшій школі повинно значно розвантажити шкільну програму та учнів, а також спростити

Професіоналізм педагога: теоретичні й методичні аспекти. - Вип. 12. - Слов’янськ, 2020. 
випускникам вступ до ВНЗ. Отже, уже зараз на місцевому рівні розробляються програми навчання в профільних школах і профтехучилищах тощо.

У педагогічній науці відсутні спеціальні праці 3 узагальненими теоретичними та практичними висновками дослідження джерельної бази 3 питання взаємодії вищого педагогічного навчального закладу й загальноосвітньої школи, тому залишається потреба в узагальненні цього матеріалу.

Для загальноосвітньої школи вищий педагогічний навчальний заклад $\epsilon$ центром педагогічної науки i вивчення, узагальнення та впровадження передового педагогічного досвіду в практику. ВПНЗ у науково-педагогічній діяльності акумулює теорію та методику навчання, розробляє нові технології навчання та виховання учнівської молоді, $є$ ініціатором нових підходів до організації навчально-виховного процесу, пропагує творчі знахідки академічної науки в практичній роботі школи.

Педагогічна теорія не встигає стежити за інноваційними розробками i модернізацією, що відбуваються в роботі вищої та загальноосвітньої шкіл у системі освіти. Суттєвим у цьому напрямку може стати вивчення й творче використання педагогічно цінних ідей і досвіду минулого. Досвід попередніх поколінь, а також розробка теоретичних і практичних здобутків $\epsilon$ джерелом розвитку й удосконалення взаємодії вищого педагогічного навчального закладу та загальноосвітньої школи.

Аналіз основних досліджень і публікацій. Проблема взаємозв'язку теорії та практики завжди залишалась актуальною і привертала увагу науковців. Так, джерельна база дослідження представлена фундаментальними теоретичними працями сучасних вітчизняних науковців щодо проблеми взаємодії вищих педагогічних навчальних закладів і загальноосвітніх шкіл в Україні (О. Адаменко (2006), Л. Ваховський, В. Галузинський, С. Годник, В. Гриньова, Н. Дем'яненко, В. Краєвський, В. Курило, Е. Моносзон, О. Попова, О. Сухомлинська, Г. Цукерман). Розв'язання різноманітних проблем пов'язаних із розвитком ідеї педагогічної взаємодії: О. Глузман, О. Друганова, О. Гончар (2011), С. Золотухіна, М. Свтух, Н. Єлізарова, Є. Каратаєва (2007), Л. Карпова, В. Курило, В. Майбородова, О. Микитюк, С. Микитюк, Н. Побірченко, Н. Пузиркова, О. Рацул та ін.

Формулювання цілей статті (постановка завдання). Мета статті проаналізувати джерельну базу дослідження 3 проблеми взаємодії вищого навчального педагогічного навчального закладу та загальноосвітньої школи в процесі єдності теорії та практики. 

загальноосвітня школа» в освітньому просторі України

Результати дослідження. Переосмислити та систематизувати проблему взаємодії «вищий педагогічний навчальний заклад - загальноосвітня школа» неможливо без якісного вивчення першоджерел, архівних документів, дисертацій, монографій, статей тощо. Якісний розвиток педагогічної науки в Україні значною мірою залежить від історичних досліджень істинної джерелознавчої бази взаємозв'язку навчальних закладів.

Джерельна база дисертацій вітчизняних учених, які зробили вагомий внесок у розробку проблеми взаємозв'язку теорії та практики в організації «вищого педагогічного навчального закладу - загальноосвітньої школи» представлена дисертаційними роботами (О. Адаменко «Розвиток педагогічної науки в Україні в другій половині ХХ століття (1950 - 2000 рр.)» (Адаменко, 2006), О. Задорожна «Управління взаємодією загальноосвітнього та вищого навчальних закладів» (Задорожна, 2012), Н. Чепурна «Науково-методичні засади розвитку системи підвищення кваліфікації педагогічних працівників України (1970 - 2004 pp.)» (Чепурна, 2005), Н. Козакова «Організаційно-методичні засади педагогічної практики майбутніх учителів початкової школи в умовах ступеневої підготовки» (Козакова, 2004)), О. Лук'янченко «Організація педагогічної практики в різних типах педагогічних навчальних закладів України (друга половина XIX - XX ст.)» (2004) та авторефератами (М. Євтух «Розвиток освіти і педагогічної думки в Україні (кінець XVIII - перша половина XIX століття)» (1996), Р. Куліш «Пути повышения эффективности педагогической практики студентов в общеобразовательной школе» (1978), В. Майборода «Становлення і розвиток національної вищої педагогічної освіти в Україні (1917 - 1992 рр.)» (1993), Г. Троцко «Теоретичні та методичні основи підготовки студентів до виховної діяльності у вищих педагогічних навчальних закладах» (1997) та ін.)).

У межах нашого дослідження докладніше проаналізуємо дисертацію О. Задорожної «Управління взаємодією загальноосвітнього та вищого навчальних закладів». Українська дослідниця на підставі аналізу філософської, психологічної та педагогічної літератури визначила зміст поняття «взаємодія», що підкреслює вагомість стосунків між середньою та вищою школами. Автор обгрунтувала узагальнення наукових підходів щодо проблеми взаємодії освітніх закладів, визначення теоретичних засад і сутності управління взаємодією загальноосвітнього та вищого навчальних закладів; проаналізувала й систематизувала нормативні та інструктивно-методичні документи для отримання об'єктивної інформації про практику організації взаємодії між ланками середньої та вищої освіти; підкреслила важливість наступності у формуванні навчально-виховної діяльності учнів і студентів. Отже, взаємодія

Професіоналізм педагога: теоретичні й методичні аспекти. - Вип. 12. - Слов'янськ, 2020. 
обумовлює сукупність впливу об’єктів одне на одного, що сприяє вдосконаленню особистості майбутнього професіонала (Задорожна, 2012).

Цю думку підтримала й О. Адаменко в дисертації «Розвиток педагогічної науки в Україні в другій половині ХX століття (1950 - 2000 рр.)». 3’ясовуючи єдність теорії та практики, вона систематизувала управління загальноосвітньою школою другої половини XX ст.; простежила динаміку змін інтересу провідних українських науковців й освітян-практиків до тих чи тих педагогічних проблем другої половини XX ст.; визначила особливості сучасних методологічних позицій та періодизацію розвитку головних педагогічних теорій в Україні в досліджуваний період; схарактеризувала прогностичні тенденції розвитку вітчизняної педагогічної науки (Адаменко, 2006).

Н. Чепурна (2005) розкрила науково-методичні засади розвитку теорії та методики організації навчального процесу в системі підвищення кваліфікації педагогічних працівників України, який грунтувався на знаннях i вміннях педагогічних працівників; виборі форм і методів навчання; передовому досвіді вчителів шкіл і викладачів ВНЗ. Зазначимо, що основні цільові позиції щодо забезпечення ефективності та якості підвищення кваліфікації вчителів упродовж другої половини ХХ століття постійно змінювалися, орієнтувалися на підняття якості викладання навчального матеріалу, методики викладання предмета, підвищення рівня самоосвіти, інтелігентності, педагогічної культури та створення творчого, дружнього педагогічного колективу школи.

Зважаючи на це, Н. Козакова (2004) розглянула педагогічну практику майбутніх учителів школи в контексті їхньої ступеневої підготовки, з одного боку, як важливу складову професійної підготовки майбутніх учителів, цілеспрямовану на систематизацію та впровадження набутих студентами знань i навичок із психолого-педагогічних, методичних, спеціальних профільних дисциплін, необхідних для успішної майбутньої професійної діяльності в загальноосвітній школі; 3 іншого боку, як засіб творчого самовираження майбутнього вчителя, формування в нього професійно значущих якостей, готовності до інноваційної педагогічної й наукової діяльності, підкреслюючи важливість взаємодії навчальних закладів.

Змістовний аналіз попередніх дисертаційних робіт показав, що науковці у своїх дослідженнях підкреслювали єдність активного спілкування вчителя та педагога, яка виявлялася у відповідних уявленнях чи опосередкованих діях педагогічного процесу. На жаль, довгий час ВПНЗ та ЗОШ існували окремо, відособлено один від одного, а тому виникала потреба в єдиному, безперервному зв’язку між цими навчальними закладами.

() ДВНЗ «Донбаський державний педагогічний університет» 
Вища освіта, зокрема педагогічна, будувалась на взаємодії учасників освітнього процесу, кожен із яких водночас був як суб'єкт, що переслідував загальні цілі, так і об'єкт для інших індивідів. Взаємодія суспільних груп студентів й учнів, студентів і вчителів - результат взаємоузгодження дій, що включали індивіда (групу індивідів), мету діяльності, конфлікт, соціальну ситуацію, представлену засобами навчання й атмосферою ВПНЗ. У вищих педагогічних навчальних закладах освіти в педагогічному процесі інші норми й цінності, інтелектуальна та емоційна взаємодія між викладачами і студентами, яка відрізняється від характеру взаємодії вчителя та учнів у школі.

Ретроспективному огляду щодо історико-педагогічних розвідок проблеми розвитку школи й підготовки вчительських кадрів присвячено низку монографій (Л. Березівська «Реформування шкільної освіти в Україні у ХХ столітті» (2008), А. Бондар «Розвиток суспільного виховання в Українській РСР $(1917$ - 1967)» (1968)) та праць (О. Гончар «Педагогічна взаємодія учасників навчального процесу в системі вищої освіти України (історико-педагогічний аспект)» (2011), М. Гриценко «Нариси з історії школи в Українській РСР (1917 - 1965)» (1966), Є. Коротаєва «Педагогическое взаимодействие и технологи» (2007), В. Майборода «Вища педагогічна освіта в Україні: історія, досвід, уроки (19171985 pp.)» (1992)).

3 переліку найбільш вагомих досліджень провідних ідей, проблеми реформування шкільної освіти XX ст. науковець Л. Березівська в монографії «Реформування шкільної освіти в Україні у XX столітті» (Березівська, 2008) зазначила, що кожний період вітчизняної шкільної освіти обов'язково розв'язував питання пов'язані з теорією і практикою; підготовкою вчителя до здійснення перетворень шкільної освіти, реалізації реформ у навчанні; змінами в економічному, суспільно-політичному житті, які впливали на педагогічні причини, результати та наслідки реформування шкільної освіти в Україні.

Вагомий внесок у дослідження проблеми педагогічної взаємодії учасників навчального процесу в системі вищої освіти України внесла О.Гончар «Педагогічна взаємодія учасників навчального процесу в системі вищої освіти України (історико-педагогічний аспект)». Автор теоретично обгрунтувала сутність поняття «педагогічна взаємодія» 3 філософського, соціальнопсихологічного та комунікативного поглядів: висвітлила специфіку розвитку кожного історичного етапу в житті суспільства, який накладав свій відбиток на організацію навчання; урізноманітнила форми педагогічної взаємодії. Водночас схарактеризувала провідні тенденції розвитку ідеї педагогічної взаємодії учасників навчально-виховного процесу. Визначила недоліки та переваги в 
організації педагогічної взаємодії викладача та студента в системі вищої освіти України в досліджуваний період (Гончар, 2011).

Розглянув зміст монографії Є. Коротаєвої (2007), ми погоджуємося 3 думкою про педагогічну взаємодію як необхідну умову в підвищенні ефективності педагогічного процесу. Науковець довела наявність педагогічної взаємодії, яка передбачає поєднання педагогічного впливу і власної активності вихованця, що виявляється у відповідних уявленнях або опосередкованих під впливом на педагога й на себе самого. Тому педагогічна взаємодія передбачає доцільну організацію спілкування учасників навчального процесу: стосунків співпраці і взаємодопомоги, широкий обмін новою інформацією, супротивний процес, прихильність учнів до дій учителя, співпереживання в радості пізнання, співучасть у розв'язанні проблемних питань і пізнавальних завдань, прагнення прийти одне одному на допомогу під час виникнення труднощів.

Отже, робота за цими напрямами суттєво вплинула на організацію взаємодії теорії і практики, сприяла впровадженню результатів наукових досліджень у шкільну практику, а саме: створенню університетських кафедр у школах. Між вищими і середніми навчальними закладами України укладалися довгострокові договори про творче співробітництво. Завдяки чому був розроблений проєкт «Навчання заради майбутнього - університетські кафедри в школах», який націлював учнів на науково-дослідну, науково-практичну діяльність, передбачав наступність у навчанні, виборі учнями профільних навчальних дисциплін, створенні та забезпеченні умов для високоякісної та змістовної підготовки старшокласників до подальшого навчання у ВПНЗ.

Поширення й розповсюдження інноваційних ідей та результатів наукових досліджень взаємозв'язку теорії з практикою відбувається і через наукові статті. Проблема взаємодії «ВПНЗ - ЗОШ», теорії та практики проаналізовано в наукових статтях вітчизняних науковців, які автори друкували на сторінках педагогічних журналів і науково-методичних збірниках «Вища освіта України», «Вища педагогічна освіта», «Вопросы психологии», «Народное образование», «Освіта України», «Початкова школа», «Педагогика», «Радянська школа», «Рідна школа», «Советская педагогика», «Шлях освіти».

Сучасні аспекти досліджуваної проблеми висвітлено в наукових статтях С. Гончаренко «Методологічні засади побудови педагогічної теорії», М. Грицай «Педагогічна практика як важлива складова підготовки вчителів середньої школи в університеті», М. Кобзєвої «Профессионально-педагогическая направленость в системе молодого специалиста», І. Прокопенка «Минуле, сучасне та майбутне педагогічної освіти в Україні», В. Тягловської та 
К. Венгловської «Співробітництво: школа і вуз», В. Чепелєва «Педагогічна наука і шкільна практика», В. Шпігало «Пізнання тонкощів педагогічної праці» тощо.

Важливість педагогічної теорії для практики розкривав також i С. Гончаренко. Він підкреслював: «Теорія, як наука в цілому, поповнюється, поглиблюється й перетворюється під впливом наукових відкриттів i узагальнення практики». Теорія та практика постійно розвивалися, змінювалися і робили свій внесок у навчально-виховний процес молодого покоління. Зв'язок теорії з практикою - це той основний камінь, на якому тримається весь фундамент педагогічної системи. С. Гончаренко переконливо довів, що теорія це система узагальнених наукових знань, які орієнтовані на пояснення сторін педагогічної дійсності, які і становлять основу практичних дій (Гончаренко, 2007).

Отже, аналізуючи джерельну базу дисертацій, підкреслимо вагомість спільної діяльності вищого педагогічного навчального закладу та загальноосвітньої школи, де чітко видно, що досягнення позитивних результатів можливе завдяки впровадженню різних методик викладання в навчальновиховний процес, зміцненню матеріальної бази всіх форм власності навчальних закладів, змістовно-методичного моніторингу підручників i навчальних посібників. У процесі дослідження взаємодії «ВПНЗ - ЗОШ» у сфері освіти великого значення набувало очікування об'єктивних результатів від учасників цього процесу. Відмінності у взаємних очікуваннях викладачів і студентів охоплювали широке коло проблем: від змісту навчально-теоретичного матеріалу до якості знань, від ефективності їхнього засвоєння до застосування на практиці.

Насамперед навчальні заклади будують свою роботу відповідно до чинних законодавчих і нормативних актів у галузі освіти. Здійснюють підготовку майбутніх учителів, перепідготовку вчительських кадрів, надають методичну допомогу вчителям шкіл в організації навчального процесу.

Висновки. Аналіз широкого спектра джерельної бази науковопедагогічного, загальнопедагогічного й історико-педагогічного характерів дає підстави стверджувати, що проблема взаємозв'язку теорії i практики в досліджуваний період була в центрі уваги філософів, психологів, педагогів та інших. Саме завдяки розробкам зарубіжних і вітчизняних учених розв'язано багато аспектів цього феномена, проте дослідники невпинно та наполегливо продовжують наукові пошуки із перевірки і систематизації ідей, положень, форм і методів взаємозв'язку теорії з практикою відповідно до реалій сучасності, які слугують основою для встановлення взаємодії «ВПНЗ - ЗОШ».

Професіоналізм педагога: теоретичні й методичні аспекти. - Вип. 12. - Слов’янськ, 2020. 
Джерельна база дослідження проблеми взаємодії «вищий педагогічний навчальний заклад загальноосвітня школа» в освітньому просторі України

У дослідженні встановлено, що для успішного вирішення умов реалізації взаємодії теорії та досвіду необхідна глибока, добре налаштована система, щоб діячі педагогічної науки порушували новітні запити школи й розв'язували їх. Питання розуміння співвідношення теорії та практики по-різному висвітлювалися в педагогіці.

3'ясовано, що в межах поставлених завдань сьогодні, як ніколи, у джерельній базі актуальним є питання про співпрацю між вищим педагогічним навчальним закладом та загальноосвітньою школою. Загальноосвітня школа готує підгрунтя для того, щоб майбутній студент пізніше став не лише висококваліфікованим спеціалістом у своїй галузі, а й освіченою людиною. У межах такої взаємодії ми повинні говорити про плідну співпрацю педагогів усіх рівнів системи освіти, що дає можливість поєднувати їхні знання, уміння, навички та досвід для ефективного вирішення нагальних проблем освіти та підвищення рівня професіоналізму.

\section{СПИСОК ВИКОРИСТАНИХ ДЖЕРЕЛ}

1. Адаменко, О. В. (2006). Розвиток педагогічної науки в Украӥні в другій половині XX століття (1950 - 2000 рр.). (Дис. д-ра пед. наук). Луганськ, Україна.

2. Березівська, Л. Д. (2008). Реформування шкільної освіти в Украӥні у ХХ столітті. Київ, Україна: Ін-т педагогіки АПН України.

3. Гончар, О.В. (2011). Педагогічна взаємодія учасників навчального процесу в системі вищої освіти Украӥни (історико-педагогічний аспект). Харків, Україна: ХНАДУ.

4. Гончаренко, С. (2007). Методологічні засади побудови педагогічної теорії. Шлях освіти, 3, 2-10.

5. Задорожна, О. М. (2012). Управління взаємодією загальноосвітнього та вищого навчальних закладів. (Дис. канд. пед. наук). Луганськ, Україна.

6. Козакова, Н. В. (2004). Організаційно-методичні засади педагогічної практики майбутніх вчителів початкової школи в умовах ступеневої підготовки. (Дис. канд. пед. наук). Київ, Україна.

7. Коротаева, Е. В. (2007). Педагогическое взаимодействие и технологии. Москва, Российская Федерация: Academia.

8. Чепурна, Н. М. (2005). Науково-методичні засади розвитку системи підвищення кваліфікації педагогічних прачівників України (1970 - 2004рр.). (Дис. канд. пед. наук). Київ, Україна.

\section{DATA BASE OF RESEARCH OF THE ISSUE OF INTERACTION "HIGHER PEDAGOGICAL EDUCATIONAL INSTITUTION - SECONDARY SCHOOL" IN THE EDUCATIONAL ENVIRONMENT}

\section{Ella Burova}

Candidate of Pedagogical Sciences,

Methodologist of the Highest Category of the Learning And Methodical Department, SHEI "Donbas State Pedagogical University" 
Джерельна база дослідження проблеми взаємодії «вищий педагогічний навчальний заклад загальноосвітня школа» в освітньому просторі України

\author{
Sloviansk, Donetsk region, Ukraine \\ ella.burova@ukr.net
}

\author{
Kostiantyn Yarovoi \\ Candidate of Pedagogical Sciences, \\ Associate Professor of the Account and Audit Department \\ SHEI "Donbas State Pedagogical University" \\ Sloviansk, Donetsk region, Ukraine \\ yarovoy_k_a@ukr.net
}

\begin{abstract}
The article reveals the data base of the study, according to which the importance of inaccessible documents, dissertations, monographs, and periodicals is substantiated. One of the problems that teachers often deal with is the lack of methodological literature with theoretical and practical conclusions on the issue of interaction between a higher pedagogical educational institution and a secondary school. Higher pedagogical educational institution is the beginning of studying scientific achievements, the improvement of scientists' and methodologists' best practices in innovative approaches to students' learning process.

The purpose of the article is to reveal by analysing the achievements of scientists, methodologists and teachers the data base of the research of the interaction of educational institutions in the inseparable connection with theory and practice.

It has been found out that Ukrainian scholars emphasize the importance of the relationship between secondary and higher education, define the concepts of "interaction", "pedagogical interaction" from a philosophical, psychological, pedagogical and social point of view, highlight the stages of decline and formation in society, which play an important role in pedagogical interaction. The issue of the theory, which is constantly expanding, improving and changing under the influence of scientific achievements and generalizations of practice, is clarified. Pedagogical interaction includes the development of theoretical and practical achievements, organization of student-teacher communication, mutual assistance and cooperation, making cooperation agreements for the future in scientific continuity, creating students' high-quality preparation of for further study at university and for work as teachers.

The importance of the data base in the interaction of the higher pedagogical educational institution - secondary school, where the fruitful work of Ukrainian scientists and educatorspractitioners in achieving positive results while strengthening creative cooperation in the development of new textbooks and manuals, introducing various teaching and learning methods in the educational process of educational institutions, internships and advanced training of teachers and educators.
\end{abstract}

Key words: source base; interaction; pedagogical process; the relationship of theory and practice; higher pedagogical education institution; secondary school.

\title{
REFERENCES
}

1. Adamenko, O. V. (2006). Development of pedagogical science in Ukraine in the second half of the twentieth century $(1950-2000)$. (Doctoral dissertation). Luhansk, Ukraine.

2. Berezivska, L. D. (2008). Reforming school education in Ukraine in the twentieth century. Kyiv, Ukraine: In-t pedahohiky APN Ukrainy.

3. Honchar, O. V. (2011). Pedagogical interaction of participants of educational process in the system of higher education of Ukraine (historical and pedagogical aspect). Kharkiv, Ukraine: KhNADU.

Професіоналізм педагога: теоретичні й методичні аспекти. - Вип. 12. - Слов’янськ, 2020. 


\section{Е. БУРОВА, К. ЯРОВИЙ}

Джерельна база дослідження проблеми взаємодії «вищий педагогічний навчальний заклад загальноосвітня школа» в освітньому просторі України

4. Honcharenko, S. (2007). Methodological bases of construction of pedagogical theory. Shliakh osvity, 3, 2-10.

5. Zadorozhna, O. M. (2012). Management of interaction between secondary and higher educational institutions. (PhD dissertation). Luhansk, Ukraine.

6. Kozakova, N. V. (2004). Organizational and methodological principles of pedagogical practice of future primary school teachers in terms of degree training. (PhD dissertation). Kyiv, Ukraine.

7. Korotaeva, E. V. (2007). Pedagogical interaction and technologies. Moscow, Russian Federation: Akademiya.

8. Chepurna, N. M. (2005). Scientific and methodological principles of development of the system of advanced training of pedagogical workers of Ukraine (1970 - 2004). (PhD dissertation). Kyiv, Ukraine.

Матеріали надійшли до редакції 15.04.2020 p. 